Original articles

J. Perinat. Med.

3 (1975) 226

\section{Some remarks concerning the fetal heart rate total dip areas}

\author{
H. Albrecht, J. Bokelmann, J. Morgenstern, H. Schmidt \\ Clinic of Obstetrics and Gynecology University of Düsseldorf
}

Received February 3, 1975 Accepted March 4, 1975.
Some reports indicate that the total fetal heart rate (FHR) deceleration areas in themselves are a sufficient parameter for assessing the fetal state $60 \mathrm{mi}-$ nutes before birth $[3,8]$. Tournaire et al. [9] ' found a correlation between the total deceleration areas, the APGAR score and the $\mathrm{pH}$ in the umbilical artery. They stressed, however, that in addition to the total FHR deceleration areas, other FHR parameters must be used in order to assess the fetal state.

We found a significant difference between normal and pathological newborn states with regard to deceleration areas [1]. This difference, however, is no larger than that between numerous other parameters, e. g. lag time, recovery time or fluctuation within the dip. Since the report of the above mentioned authors leaves the impression that the total deceleration areas during the last phase of delivery, independently from other FHR parameters, are a reliable indicator of the fetal state, it seemed worth while to re-examine this question.

\section{Material and methods}

Using a computer program numerous dip parameters, such as the amplitude, duration, lag time, decrement time, recovery time and fluctuation before, within and after the dip determined from digitalized cardiotokograms (CTG) (technique of Morgenstern et al. [5]). Cardiotokograms were computed in 385 patients, 255 with normal newborns (normal newborn index) and 130 with pathologically altered newborns (pathological index). This newborn asphyxia index includes essentially the Apgar score after 1,5 and 10 minutes, the performed reanimation proce- dures, and the adaptation of the newborn during the first seven daỳs of life. Only those CTG sectors occurring $60 \mathrm{~min}$. before delivery and showing at least two decelerations were included. This reduced the number of normal newborn indices to 62 and those with pathological indices to 40. Only the state of the newborn was considered [6]. Thus a selected group of e. g. pregnancies at risk or certain pathological CTG courses was avoided. In both groups CTGs were computerized.

\section{Results}

In order to compare our data with those of TouRNAIRE et al. [9] the total FHR dip areas were determined. Fig. 1 shows Tournatre's mean values on the left. This was, as stated by TournaIre, a selected group with numerous or severe decelerations and pregnancies at higher risk. The difference between his two groups is highly significant ( $p<0.001$, separate variance t-test), i. e. Apgar scores below seven are more often associated with large total deceleration areas.

Our data are shown on the right side of Fig. 1. Only cardiotokograms with at least two decelerations were used in both groups. The mean of the total dip areas is larger in the group with a pathological newborn index than in the normal one, but this difference is not significant using either the t-test or the WILCOXON test*). This result shows that the total dip areas alone are an unreliable parameter from which to judge the fetal state. It seemed of interest to examine the

*) As suggested by K. Schmidt, Inst. for Med. Statistics and Documentation, Steglitz Clinic, Bërlin 
TOURNAIRE ET AL. SELECTED GROUPS

OWN RESULTS UNSELECTED GROUPS

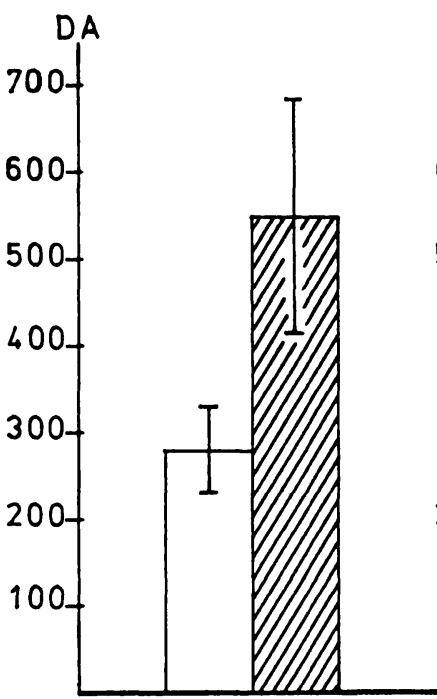

APGAR $1 ' \geq 7, N=66$

DID APGAR $1 \leq 6, N=20$

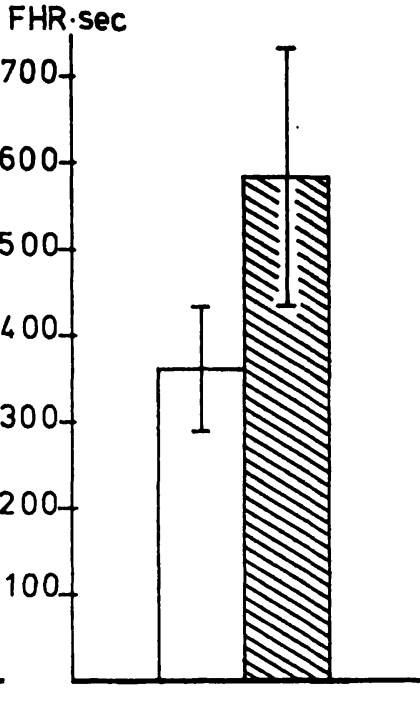

NORM. INDEX, $N=62$

SW PATH. INDEX, $N=40$
TOTAL DIP AREAS

Fig. 1. Means of the sum of total dip areas of cardiotokograms from normal and pathological newborns.

Tournaire et al., $\mathrm{p}<0.001$ separate variance test. Own results, not significant in t-test and WiLcoxon test.

behavior of other dip parameters during the last $60 \mathrm{~min}$. before delivery. Hence for a few descriptive parameters, e.g. the fluctuation of FHR before, within, and after the dip, the mean was determined for these 60 minutes. Fig. 2 shows differences between the two groups (normal and pathological newborn indices) are only slight. It follows that the fetal state can hardly be determined from another single parameter.

The prediction of the fetal state can be improved by simultaneous consideration of several descriptive dip parameters (SchmIDT et al. [7]). The various descriptive parameters of each deceleration were given different weights depending on their value and were added. In this way a valuating parameter was calculated for each deceleration. In order to obtain this parameter the fluctuation of the FHR before, within, and after the dip,

Fig. 3. Means of the sum of total dip areas (not significant) and the sum total of evaluating dip parameters $(p<0.01$ in t-test and WiLcoxon test).
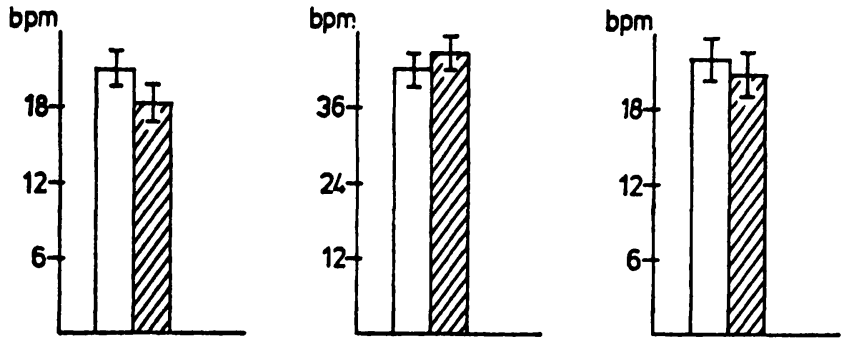

BEFORE

WITHIN

AFTER
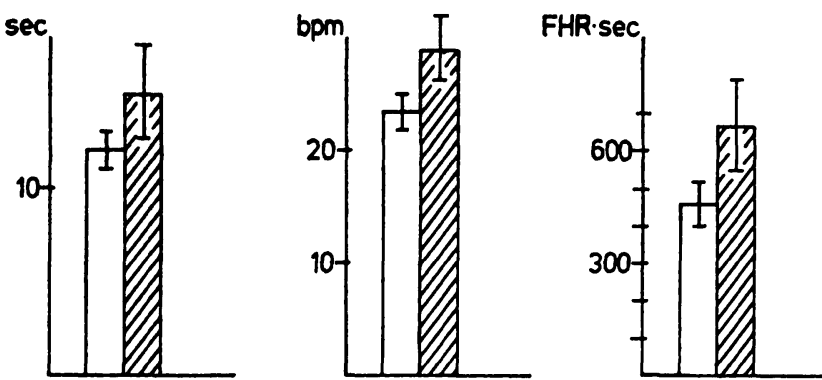

MEAN LAG TIME MEAN AMPLITUDE

MEAN AREA

$\square$ NORM. NEWBORN INDEX $N=62$

mim PATH. NEWBORN INDEX $N=40$

Fig. 2. Mean values of different mean dip parameters.
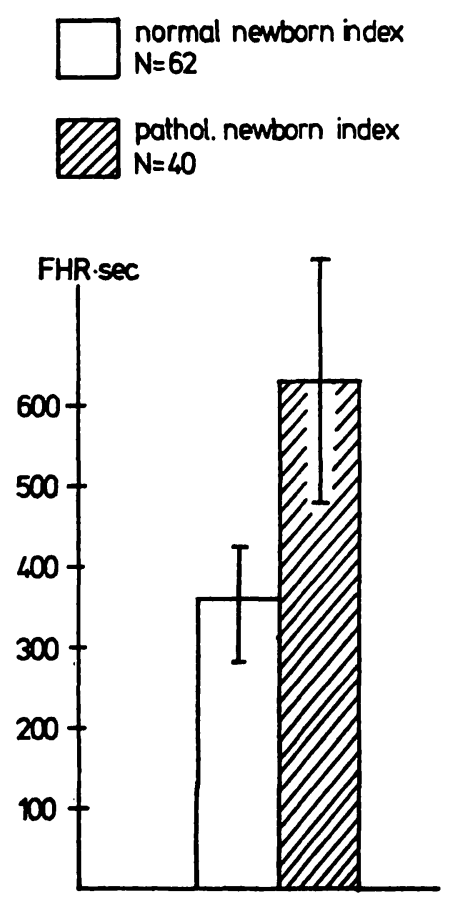

TOTAL DIP AREAS

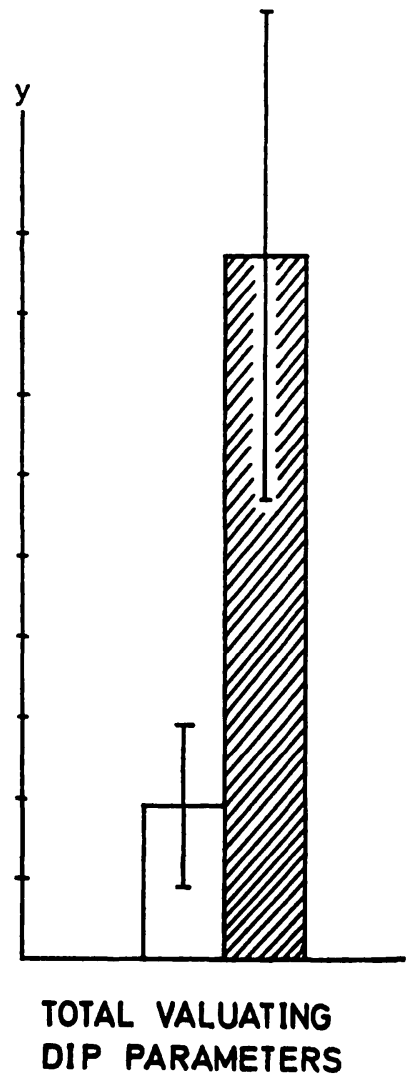

J. Perinat. Med. 3 (1975) 
the decrement time, the amplitude, the recovery time, the duration at dip minimum, the duration at half amplitude and the total dip duration were all taken into account.

The sum of total valuating dip parameters in both groups was calculated for each CTG run in a way similar to the total dip areas. The means of the dip areas in both groups were compared with the means of the total valuating dip parameters (Fig. 3). The two groups differ significantly (t-test $p<0.01$, WiLcoxon Test $\mathrm{p}<0.01$ ) when the total valuating dip parameters are considered, which was not the case with the sum total of the dip areas.

\section{Discussion}

We have shown that the total dip areas differ only slightly between normal and pathological newborn states. We think that the fetal state cannot be evaluated satisfactorily from the

\section{Summary}

It was ascertained whether the sum total of the dip areas 60 minutes prior to delivery is an evaluating parameter for judging the fetal state. The cardiotokograms of 62 deliveries with a normal newborn state (newborn index 1) and forty with a pathological newborn state (newborn index 2 and 3) were digitally computed [5]. By proper programming numerous descriptive dip parameter can be determined, e. $g$. the amplitude, duration, area, lag time, recovery time, fluctuation before, within, and after the dip.

The sum total of the dip areas was calculated from the CTG 60 minutes before delivery. Only cardiotokograms with at least two decelerations were included. The pathological newborn group has a larger mean sum total of dip areas than the group with a normal index (Fig. 1). This difference, however, is not significant. Mean values were calculated for other descriptive parameters, e. g. dip fluctua- total dip areas. Prediction is already improved, when two parameters, e. g. recovery time or dip fluctuation together with the lag time are considered [1]. Kimura [4] and Hammacher [2] developed a FHR score for visual evaluation of cardiotokograms. This FHR score considers as many parameters as possible, each receiving a different number of points depending on its weight. Both authors claim that the fetal state is better evaluated by this score. For the dip valuating parameter computed by us descriptive dip parameters are considered and evaluation occurs through statistical calculations using discrimination analysis. The calculated weights of the dip parameters agree with clinical experience [7]. Our results have already significantly improved the assessment of the fetal state although the dip valuating parameter is only a part of our routine CTG evaluation.

tions, lag time, dip amplitude etc. These also differ only slightly between the two groups. (Fig. 2). Hence they give no satisfactory decription of the fetal state.

By including several dip parameters simultaneously [7] an evaluating parameter can be determined for both decelerations. The various descriptive parameter are given different weights and are added up (discrimination analysis). In analogy to the sum total of the dip areas the sum total of the evaluating parameters was calculated. The difference between the two groups with respect to these evaluating parameter sums is significant. (Fig. 3). The sum of total dip areas alone does not appear to be a sufficient FHR parameter for evaluating the fetal state. Evaluation is significantly improved by considering simultaneously several descriptive parameters.

Keywords: Asphyxia index, deceleration, deceleration parameter, digitally computerized data, electronic data treatment, fetal heart frequency, fetus.

\section{Zusammenfassung}

Einige Bemerkungen über die „total dip area“ bei der fetalen Herzschlagfrequenz

In der vorliegenden Arbeit ist untersucht worden, ob die Summe der Dip-Flächen in der Zeit $60 \mathrm{~min}$ vor der Geburt für die Beurteilung des fetalen Zustandes ein aussagekräftiger Parameter sei. Dazu wurden die Kardiotokographie-Verläufe von 62 Geburten mit einem normalen Neugeborenenzustand (Neugeborenenindex 1) und $40 \mathrm{Ge}-$ burten mit einem pathologischen Neugeborenenzustand (Neugeborenenindex 2 u. 3) digitalisiert [5], d. h. für die Auswertung mit einem Computer aufbereitet. Durch ein Programmsystem lassen sich zahlreiche beschreibende Dip-
Parameter wie z. B. die Tiefe, Breite, Fläche, lag time, Abstiegszeit, Anstiegszeit und die Fluktuation vor, im und nach dem Dip bestimmen.

Aus den CTG-Abschnitten 60 min vor der Geburt ist die Summe der Dip-Flächen berechnet worden. Werden dabei nur Kardiotokogramme mit mindestens zwei Dezelerationen zugelassen, so ist in der Gruppe mit einem pathologischen Neugeborenenindex im Mittel die Summe der Dip-Flächen größer als in den Gruppen mit einem normalen Index. Der Unterschied ist jedoch statistisch nicht signifikant (Abb. 1). Für einige andere beschreibende Parameter wie z. B. die Fluktuation im Dip, 
die lag time, die Dip-Tiefe usw, werden die Durchschnittswerte über die $60 \mathrm{~min}$ CTG-Strecke berechnet. Die untersuchten, beschreibenden Dip-Parameter unterscheiden sich bezüglich der beiden Kollektive ebenfalls nur gering (Abb. 2) und lassen keine befriedigende Beurteilung des fetalen Zustandes zu.

Durch die gleichzeitige Berücksichtigung von mehreren Dip-Parametern [7] läßt sich für beide Dezelerationen ein bewertender Parameter bestimmen. Dabei werden die beschreibenden Dip-Parameter mit verschiedenen Gewichten versehen und aufaddiert (Diskriminanzanalyse). Analog zur
Summe der Dip-Fläche ist die Summe der bewertenden Dip-Parameter berechnet worden. Im Gegensatz zur Summe der Dip-Flächen unterscheiden sich die beiden Kollektive bezüglich der Summe der bewertenden DipParameter signifikant (Abb. 3). Die Summe der DipFlächen scheint allein kein ausreichender FHR-Parameter zu sein. Dagegen führt die gleichzeitige Berücksichtigung mehrerer beschreibender Dip-Parameter zu einer signifikanten Verbesserung in der Beurteilung der FHR.

Schlüsselwörter: Asphyxieindex, Dezelerationen, Dezelerations-Parameter, digitalisierte Daten, elektronische Datenverarbeitung, fetale Herzfrequenz, Fetus.

\section{Résumé}

Quelques remarques sur les surfaces Dip totales du rythme cardiaque foetal

Dans les présent aricle, on s'est posé la question de savoir si la somme des surfaces Dip dans le temps de $60 \mathrm{~min}$ avant la naissance représente un paramètre suffisant sur l'état du foetus. A cet effet, on a digitalisé les tracés cardiotocographiques de 62 accouchements avec un état de nouveau-né normal (index de nouveau-né 1) et de 40 accouchements avec un état de nouveau-né pathologique (index de nouveau 2 et 3) [5], c. à. d. qu'on les a préparés pour évaluation par computer. Un système programmé permet de définir de nombreux paramètres Dip descriptifs tels que, par ex., la profondeur, la largeur, la surface, le lag time, le temps de décroissance, le temps de croissance et la fluctuation avant, pendant et après le Dip.

La somme des surfaces Dip a été calculée à partir des segments CTG 60 min avant l'accouchement. Si on ne retient que les cardiotocogrammes avec au moins deux décélérations, on constate qu'en moyenne la somme des surfaces Dip est plus grande dans le groupe à l'index de nouveauné pathologique que dans celui à l'index de nouveau-né normal. La difference n'est toutefois, pas significative sur le plan statistique (Fig. 1). Pour divers autres paramètres descriptifs tels que, par ex., celui de la fluctuation dans le Dip, du lag time, de la profondeur Dip etc., on a calculé les valeurs moyennes sur le tracé CTG de $60 \mathrm{~min}$. Les paramètres Dip descriptifs examinés ne diffèrent guère davantage entre les deux groupes (Fig. 2) et n'autorisent aucune appréciation satisfaisante de l'état foetal.

En tenant compte à la fois de divers paramètres Dip [7] il est possible de définir un paramètre évaluable pour les deux décélérations. Les paramètres Dip descriptifs sont, à cet effet, munis de divers poids et additionnés (analyse discriminatoire). De façon analogue à la somme de la surface Dip, on calculate la somme des paramètres Dip évaluables. Au contraire de la somme des surfaces Dip, les deux groupes diffèrent de façon significative en ce qui concerne la somme des paramètres Dip (Fig. 3). La somme des surfaces Dip ne semble pas suffire à elle seule comme paramètres FHR pour évaluer l'état foetal. Par contre, la consideration simultanée de plusieurs paramètres Dip des criptifs permet d'améliorer de façon significative l'appréciation du FHR.

Mots-clés: Calcul électronique de données, décélérations, données digitalisées, foetus, fréquence cardiaque foetale, index d'asphyxie, paramètre de décélération.

Acknowledgment: This work was supported by the Ministry of Science and Research, State of Nordrhein-Westfalen, Landesamt für Forschung.

\section{Bibliography}

[1] Albrecht, H., J. Bokelmann, J. Morgenstern, H. Schmidr: Computed dip-parameters derived from digitized FHR-curves II. The value of descriptive parameters. J. Perinat. Med. 2 (1974) 260

[2] Hammacher, K.: Die semiquantitative Auswertung von Kardiotokogrammen anhand eines CTG-Scores. In: Saling, E., J. W. Dudenhausen: Perinatale Medizin, Bd. VI., Thieme, Stuttgart 1975

[3] Kastendieck, E., W. KünZEL, P. ZrmmermanN: Quantitative relationsships between slowing of the fetal heart rate and changes in base exess in the second stage of labor. J. Perinat. Med. 2 (1974) 106

[4] Krmura, S.: Studies on fetal heart rate changes related to the conditions of fetus and newborn. Acta Obstet. Gynaec. Jap. 18 (1971) 127

[5] Morgenstern, J., H. Albrecht, J. Bokelmann, H. SCHMIDT: Computed dip-parameters derived from digitized FHR-curves I. The describing parameters and the method of digitizing, J. Perinat. Med. 2 (1974) 254 
[6] Schmidt H., J. Morgensternn: Beiträge zur Erforschung der Herzfrequenz des Feten aus verschlüsselten Daten. I. Programmsystem zur Auswertung klinischer Daten. Geburtsh. u. Frauenheilk. 33 (1973) 929

[7] Schmidt H., H. Albrecht, J. Morgenstern, J. BokelmanN: Computed dip-parameters derived from digitized FHR-curves III. The valuating parameter J. Perinat. Med. 2 (1974) 268
[8] Shelly T., R. H. Trpton: Dip Area. A quantitative measure of fetal heart rate patterns. J. Obstet. Gynaec. Brit. Cwlth. 78 (1971) 694

[9] Tournatre M., S. Y. Yeh, A. Forsythe, E. Hon: A study of fetal heart rate deceleration areas. Obstet. Gynaec. 42 (1973) 711
Dr. H. Albrecht Univ.-Frauenklinik Moorenstr. 5

D-4000 Düsseldorf 1 Germany 